\title{
DE RIOS, MARGENS E TRAVESSIAS: TRÊS ESTÓRIAS DE GUIMARÃES ROSA
}

\author{
Maria Lucia Guimarães de Faria* \\ "amo os grandes rios, pois são profundos como a \\ alma do homem" \\ GuimarâEs Rosa
}

As estórias rosianas são atos inaugurais de um viver. Assinalam o instante em que o homem deixa de sobreviver relesmente e se proclama autor de sua própria existência. Este projeto emancipatório se evidencia na estória central de Primeiras estórias, "O espelho". O "julgamento-problema" - "Você chegou a existir?" (ROSA, 1981, p. 68) formula-se a modo de proposta seminal que abissalmente fecunda todas as estórias que se narram. Para além deste livro, a provocação também se responde nas Terceiras estórias. Aqui, o desafio é superar a "posiçáo-limite de irrealidade existencial ou de estática angústia", ultrapassando "a goma arábica da língua quotidiana" e desvencilhando-se do "círculo-de-gis-de-prender-peru", onde vegeta o "inerme, humano, inerte" (ROSA, 1979, p. 4). A grafia insólita de "giz" por gis se reporta ao verbo francês gésir (je gis, tu gis, il git...), que significa "jazer". A expressiva criação transidiomática, aliada aos quatro hífens que prendem as palavras umas às outras e à própria ideia do círculo de giz, acentua o estatismo e a passividade de que urge libertar-se. As três estórias que se analisam a seguir não apenas compartilham o propósito de responder à ingente questão do existir, como também se irmanam no atender ao chamado das águas, em cuja permanente deveniência imprime-se um convite à metamorfose.

\section{O RIO - PONDO PERPÉTUO: "A terceira margem do rio"}

"A terceira margem do rio" (ROSA, 1981, p. 27-32) é uma autêntica narrativa de 1a pessoa, na qual narrar equivale a prospectar o sentido da própria existência. Toda a vida do narrador é dedicada a tentar decifrar o alcance da extremada atitude do pai. Mais do que isso, toda a sua vida é pendente desse "assunto que jogava para trás seus pensamentos" (p. 29). Entretanto, ele jamais consegue compreender o grandioso gesto

* Professora Adjunta de Literatura Brasileira da Universidade Federal do Rio de Janeiro - UFRJ. 
do pai, razão pela qual ele é aquele que não chegou a existir, "o que vai ficar calado" (p. 32). Seu "falimento" no instante do salto mortale acarreta o desrumo de uma vida precocemente abortada. O pai, por outro lado, é aquele que ousou o mergulho no abismo. $\mathrm{O}$ contraste entre os dois constitui a chave da estória. $\mathrm{O}$ fato de o narrador ser o filho, que retrocedeu, e não o pai, que ultrapassou, mostra concretamente o aspecto dilacerante de não chegar a existir.

Como o narrador de "O espelho" antes da experiência-limite, o pai "era homem cumpridor, ordeiro, positivo, e sido assim desde mocinho e menino" (p. 27). O emprego insólito do particípio passado "sido", feita a elipse do verbo auxiliar, destaca de forma notável a passividade por que se havia pautado a existência do pai. Dele esperava-se sempre o previsível. Mas, certo dia, "se deu" o diferente: "nosso pai mandou fazer para si uma canoa" (p. 27). Com esse ato, o pai realiza uma ruptura radical com toda a sua vida pregressa e, sem nada dizer, embarca numa viagem sem volta, que passa a constituir o seu próprio existir:

Nosso pai não voltou. Ele não tinha ido a nenhuma parte. Só executava a invenção de se permanecer naqueles espaços do rio, de meio a meio, sempre dentro da canoa, para dela não saltar, nunca mais. $\mathrm{A}$ estranheza dessa verdade deu para estarrecer de todo a gente. Aquilo que não havia, acontecia (p. 28).

A frase que anuncia a radical virada da vida do pai é de grande impacto: "Aquilo que náo havia, acontecia". Algo inteiramente novo aqui se propóe. O insólito, o inusitado, o inaudito, vêm a ser. Emancipando-se da passividade pregressa, o pai faz acontecer. A vírgula, gramaticalmente indevida, é semanticamente eloquente no assinalar a ruptura entre o que até então não fora e o que se pôs a ser.

Cursar no rio, "solto solitariamente" (p. 28), é a nova modalidade de ser em perpétuo devir que o pai inventa para si. Adotar o rio "grande, fundo, calado que sempre" como morada, fundir-se com o movimento incessante das águas, é executar, em caráter irrevogável, a travessia para o silêncio e para a solidão, que, para Guimarães Rosa, "equivale ao infinito", conforme declara em entrevista a Günter Lorenz (LORENZ, 1973: 329). O rio, semelhante em profundidade e mobilidade à alma humana, é o espaço adequado ao florescimento de todas as potencialidades que jazem dormentes no espírito do homem:

...amo os grandes rios, pois são profundos como a alma do homem. Na superfície são muito vivazes e claros, mas nas profundezas são tranquilos e escuros como os sofrimentos dos homens. Amo ainda mais uma coisa de nossos grandes rios: sua eternidade. Sim, rio é uma palavra mágica para conjugar eternidade (LORENZ, 1973, p. 328/329).

A travessia para a solidáo é a jornada da alma que promove o encontro decisivo do ser consigo mesmo. $\mathrm{O}$ triunfo da conquista de um destino próprio depende desse encontro, que é inteiramente pessoal, incomunicável mesmo à alma mais fraternalmente próxima, menos ainda traduzível em termos de troca social. Ele é fruto de uma 
longa busca, trabalho de uma vida inteira. O ser humano possui uma dupla dimensão, que implica a ideia do seu próprio ser na 2a pessoa. Quando o homem se recolhe em si mesmo, descobre que, no fundo de sua solidão, não se encontra isolado, mas, nas palavras de Plotino, está "sozinho com o Sozinho" (Enn. VI, 9, 11). O encontro essencial é a reunião dessas duas solidôes, que se aparentam e se confeiçoam uma à outra. $\mathrm{O}$ ser divino necessita do homem para sair do seu estado de indiferenciaçáo e manifestar-se; o ser humano precisa de Deus para ser investido com a existência. A relação entre o humano e o divino fundamenta-se numa paixão recíproca e num movimento mútuo de procura. (CORBIN, 1981).

"Do que eu mesmo me alembro, ele náo figurava mais estúrdio nem mais triste do que os outros, conhecidos nossos. Só quieto", informa o narrador a respeito do pai (p. 27). A quietude externa é o requisito essencial para o trabalho interior. A travessia para a solidão exprime a intensa busca das potencialidades últimas que caracterizam o ser humano e o desejo de transcender as humanas limitaçóes, que impedem o contato com realidades mais vastas. Esse anelo concretiza-se numa mudança interior, numa remodelagem íntima. A transfiguração abole uma desarmonia da qual se tinha aguda consciência. Re-generaçấo torna-se a palavra de ordem (UNDERHILL, 1955, p. 128).

A verdadeira açáo, portanto, é a do espírito, que se concentra em si mesmo. Plotino estabelece uma distinção entre praxis e poiesis. Para ele, praxis é uma ação impura, porque escrava de necessidades externas. A ação que verdadeiramente constrói o ser é poiesis, expressão de uma plenitude que se prodigaliza sem esgotar-se, e que, mesmo quando irradia de si a vida, não sofre qualquer redução. Esta ação é a manifestação de um entusiasmo, em que o homem devém outro, ao fazer coincidir o seu próprio centro com o núcleo do cosmos. Êxtase, abandono de si, busca de contato, rapto, esta ação é, por outro lado, também, consciência de um ajuste íntimo, atenção ao que jaz mais recôndito, encontro consigo mesmo, e é por isso que ela garante a conquista da unidade interior e assegura a fecundidade do espírito. Somente o homem que se volta para dentro é capaz de tornar-se o princípio de si mesmo, e apenas para ele vale a igualdade de Plotino, segundo a qual theoria (contemplação) = poiesis (criação) $($ ARNOU, 1921). Quem ousa superlativamente como o pai e empreende a travessia para a solidáo passa a viver em estado de criatividade permanente, invencionando o seu ser no puro in fieri do devir.

O espírito é um movimento inflamado que visa à plenificação, livrando o homem das amarras que o mantêm numa condição de imanentização forçada. Acima de tudo, o espírito é liberdade (BERDIAEV, 1984). Paradoxalmente, a solidão não isola, mas constitui o passaporte para a comunhão cósmica da alma. O solitário já está consigo mesmo, o que significa receptividade total. A revelação não é uma luz projetada do exterior, mas um acontecimento interior, uma claridade que jorra de uma profundidade abissal. Só se revela a mim aquilo que se revela em mim. Acontece para mim aquilo que nấo havia e eu faço acontecer. O real é uma infinitude sempre dinâmica; ele só se dispóe a uma vida que possua as mesmas propriedades. Mundos inteiros perma- 
necem inaccessíveis à nossa experiência, porque a parede de nossa consciência no-los afastam.

O homem nasce dotado com a liberdade de ser. Ao realizar a travessia para a solidáo, é com a liberdade abissal, raiz do ser, que ele se intimiza. A liberdade é a dinâmica interior do espírito, o mistério do ser. Ela é a fonte sombria da vida, a experiência original, o abismo que se encontra a uma profundidade insondável e que Jacob Boehme denomina Ungrund (sem fundo). Na origem do mundo, encontra-se uma liberdade irracional, enraizada nas profundezas do nada. Estas trevas abissais náo podem ser racionalizadas: nelas permanecem ocultas as condiçóes de afluxo de novas energias obscuras e criativas. A luz do Logos triunfa das trevas, a harmonia cósmica prevalece sobre o caos, mas sem o abismo das trevas e do caos não haveria vida, liberdade ou significação. A liberdade jaz no vórtice sombrio, mas sem ela tudo é destituído de sentido. Ela engendra o mal e o bem. O homem sente em si mesmo, no princípio de seu ser, essa liberdade irracional, que se liga à energia potencial e elementar. Privado da liberdade do mal, o homem não seria mais que o autômato do bem. Trágico é o destino da liberdade, trágica é a vida humana. A liberdade sem mesura de onde provém o homem náo garante que ele seguirá o caminho do bem. Dinâmica por natureza, ela pode facilmente degenerar em seu contrário. A liberdade é austera e difícil. Ela é uma concentração, e não uma dissipação do espírito. A vida fácil é a que se passa na necessidade e na obrigação. A liberdade, por outro lado, gera sofrimento, e, por isso, a renúncia a ela traz um aparente alivio às dores da vida (BERDIAEV, 1984).

Mais fundamental do que a salvaçáo da alma é a realização da natureza criativa. $\mathrm{O}$ ato criador supóe uma superabundância, um impulso irreprimível, a demanda de uma integralização. A criaçáo é a constituiçáo de um poder novo tirado do não-ser, a plasmaçáo de algo que náo existia. A tarefa do homem é construir o inédito, como a terceira margem do rio. $\mathrm{O}$ curso do mundo não pode ser somente o resgate do pecado, a vitória sobre o mal. O gesto criativo outorga um ganho absoluto, um adensamento existencial, um acréscimo de ser. $\mathrm{O}$ acontecimento espiritual mais importante é a autorrevelaçáo do homem. Um sentimento de si mesmo como agente final de seu destino, uma espécie de autoconsciência apocalíptica, podem conduzir o homem a uma vida nova, porque consolidam um impulso criador (BERDIAEV, 1955).

A via espiritual é perigosa, contudo. A vida ordinária, pelo contrário, a religiáo feita de costumes e de gestos exteriores, oferecem um máximo de segurança. Toda a iniciativa criativa esconde um risco, sem o qual o espírito se atrofiaria. $\mathrm{O}$ mistério não é uma categoria negativa, um limite, mas um limiar; ele resume a profundidade infinita da vida. Se o mistério desaparecesse, tudo se tornaria superficial e raso. O homem é avocado pelo mistério, que o convida como um chamamento pátrio. Como ensina Rilke, a solidão não é uma coisa que podemos tomar ou deixar: somos nós (RILKE, 1989, p. 65). Esta verdade, que deu para estarrecer de todo a família, foi a descoberta abissal que o pai desentranhou de si. 
Aderidos ao agora, tementes ao novo, os familiares não podiam atinar com o arrojo do pai. Como explicar a outrem um chamado que é só abismo, um gesto tecido em mistério, o ingresso num espaço inaudito, um acontecer ainda informe e infante, uma celebração festejada em silêncio e sigilo? "Nosso pai nada não dizia" (p. 27). Os acontecimentos decisivos ocorrem numa dimensão onde nenhuma palavra nunca pisou. "Muita coisa importante falta nome", afirma Riobaldo (ROSA, 1970, p. 86). Na fala de despedida da mãe, a intransponibilidade da distância que se abre já está selada para sempre: " - Cê vai, ocê fique, você nunca volte!" (p. 27). A gradual distensão da síncope "cê" exprime concretamente a separação que se decreta, a perda da intimidade. $\mathrm{O}$ tratamento solene "você" assina o afastamento que nunca mais seria vencido. $\mathrm{O}$ pai partiu em busca do derradeiro horizonte da experiência humana, a fim de inaugurar-se numa nova feição de ser; os outros ficaram, aferrados a si mesmos, escravos da identidade.

Por que o temor de partir, de deixar-se ir no curso das águas? Porque empreender a travessia para a solidão significa morrer. Entretanto, quem se furta a morrer náo chega a existir. A suprema distinção do homem é o seu dom de morte, a sua aptidão para morrer. Nós somos "os infinitamente mortos" (RILKE, 1943, 102 - Elegia X). Todas as coisas perecem, mas nós somos os mais perecíveis, todas as coisas passam, transformam-se, mas nós desejamos passar, nós almejamos a transformação, nós nos plenificamos nesse dom de transcender (BLANCHOT, 1955, p. 182). Quem se fecha em imobilidade já petrificou-se. Viver é, já de si, dizer adeus. Nós podemos, no entanto, nos adiantar ao momento da separação final e, desde já, tocar o abismo, ter acesso ao ser profundo. Daí o apelo do poeta, que bem traduz o sentido primordial da aventura solitária do pai: "Aspira à metamorfose" (Wolle die Wandlung) (RILKE, 1943, p. 216 - Soneto XII, 2a parte).

De todas as pessoas da família, o filho mais velho, narrador da estória, é o único que chega ao limiar de uma intuição reveladora. Mais próximo ao pai - "Tiro por mim, que, no que queria e no que não queria, só com nosso pai me achava" (p. 29) ele é tocado pela grandeza daquela decisão extrema, que o encanta, espanta e atormenta, a tal ponto que deseja compartilhá-la: "Só fiz, que fui lá. (...) Eu estava muito no meu sentido" (p. 31). Todavia, ele jamais chega a compreendê-la. Para ele, ela não brota em luz interior, capaz de banhá-lo na aurora de um novo sentido. Por isso, ele é "o que não foi". Nas formas do pretérito perfeito, confundem-se o verbo ir e o verbo ser. "O que náo foi" tanto é o que deixou de ir, como o que negou-se a ser: "Eu fiquei aqui, de resto. Eu nunca podia querer me casar. Eu permaneci, com as bagagens da vida" (p. 30/31). Bagagens, aqui, valem por "fardo", que mais pesado se torna com o "demoramento" que é o passar da vida. Permanecer parado equivale a ficar calado. Ao invés de expandir-se na aquisição de novas linguagens no puro trato com o silêncio, ele se apequenou num enredo de culpa e expiação, e ficou refém de um mutismo imposto, todo feito de carência, de parcas pobres palavras, que contrasta agudamente com a opulência do silêncio do pai: 
Sou homem de tristes palavras. De que era que eu tinha tanta, tanta culpa? Se o meu pai, sempre fazendo ausência: e o rio-rio-rio, o rio - pondo perpétuo. Eu sofria já o começo de velhice - esta vida era só o demoramento (p. 31).

O pai "nunca mais falou palavra, com pessoa alguma" (p. 30), porque o que ele tinha a falar não cabia em dizer, excedia em muito a capacidade dos outros de escutar. O filho ficou calado porque, estagnando-se na iminência do grande salto, estancou em si o fluxo da vida, e, com ela, a possibilidade de exprimir algo novo. Em trabalho intitulado "A margem à margem das margens", Alexandre Mendonça esclarece que "o silêncio do pai se diferencia pela sua potência de escapar aos códigos instituídos e criar outras possibilidades de expressão", ao passo que "o que leva os outros ao silêncio é o fracasso em aprisionar a viagem nômade nas regras do pensamento dogmático" (MENDONÇA, 1996, p. 27).

O filho, por fim, logra expressar-se como o narrador de uma narrativa que traduz o anelo desesperado de, ao menos na morte, igualar-se ao pai, depositando-se na deveniência do rio. O pai, contudo, morre em vida. Antecipando-se ao grande adeus, ele busca por si mesmo o abismo e realiza a travessia para a terceira margem do rio em plena posse de suas forças vitais. Para ele, cai a barreira que normalmente separa o aquém e o além. $\mathrm{O}$ resultado é um viver infinitamente mais pleno, no qual todas as dimensôes se conjugam na plasmação de uma supra-dimensáo em que o natural e o sobrenatural, o humano e o divino, o ser e o não-ser não mais se distinguem. $\mathrm{O}$ filho, porém, necessitaria da morte real para fazer-se ao outro lado. Faltou-lhe a coragem em face do estranho e do inaudito: "E eu não podia... Por pavor, arrepiados os cabelos, corri, fugi, me tirei de lá, num procedimento desatinado. Porquanto que ele me pareceu vir: da parte de além" (p. 32). Somente quem está preparado para tudo pode ir até o fundo da sua existência.

A diferença entre o pai e o filho ressalta de forma ainda mais pungente no paralelismo de duas construçôes, que contrapóem as duas orientaçôes existenciais:

Se o meu pai, sempre fazendo ausência: e o rio-rio-rio, o rio - pondo perpétuo" (p. 31). E estou pedindo, pedindo, pedindo um perdáo" (p. 32).

O ritmo ternário e a coliteração do $/ \mathrm{p} /$ e do $/ \mathrm{d} /$, presentes em ambas as frases, acusam, por contraste, a enorme distância que separa as duas atitudes. O pai é a pura deveniência do fluir sempre alterno do rio, cuja perpetuidade advém do infinito diferir de si mesmo. O filho expia a culpa do que nem sabe, "de dor em aberto", em seu foro (p. 31), como se a vida humana não fosse mais do que o resgate de pecados ou a condenação antecipada do Juízo Final. Entretanto, a única culpa que ele carrega é a de ser pouco. $\mathrm{O}$ homem que não ousa não potencializa a sua natureza criadora, e quem não cria avassala-se, de antemão, ao estabelecido. $\mathrm{O}$ que existe são duas margens, que constrangem duplamente a existência. A terceira margem é a transcensão de fronteiras, a superação das dualidades antagônicas, a liberdade, a criatividade, o novo como promessa de vida. Se o ser fosse unitário, ele permaneceria em estado embrionário, embu- 
tido em si mesmo; como dualidade, ele se manteria desesperadamente dividido, apartado de si próprio; é como trinitaridade que desabrocha a sua plenitude, o seu encontro consigo mesmo, o triunfo sobre a desarmonia, dentro e fora de si. O três é a unidade que conserva a diferença. $\mathrm{O}$ ser como trindade conquista a redondeza do repousar serena e solitariamente sobre o diálogo que abissalmente somos. Ao transcender a aporia das duas margens, o pai iguala-se ao rio. Ao retroceder diante do inominável, o filho abrevia-se para a vida. Quem não se arroja além não habita, tampouco, aquém. $\mathrm{O}$ homem não deve precipitar-se diante do mistério, mas, seguindo o conselho do poeta,

aguardar com profunda humildade e paciência o parto de uma nova claridade. (...) Aí o tempo não serve de medida: um ano nada vale, dez anos não são nada. Náo se trata de calcular e contar, mas, sim, de amadurecer como a árvore que náo apressa a sua seiva e enfrenta tranquila as tempestades da primavera, sem medo de que depois dela não venha nenhum verão. $\mathrm{O}$ verão há de vir. Mas virá só para os pacientes, que aguardam num grande silêncio intrépido, como se diante deles estivesse a eternidade" (RILKE, 1989, p. 32/33).

\section{A SUSCITADA: "Azo de almirante"}

Para libertar-se do círculo-de-gis-de-prender-peru e suplantar a estática angústia, o homem precisa "outrar-se". Tornar-se outro significa singularizar-se, não se acomodando à mediocridade e não se parecendo mais com ninguém. Hetério descobriu a própria alteridade no devir alterno das águas do rio e suscitou a novidade de caráter ao se entregar à terceira margem de um rio-rio-rio que punha perpétuo. Chegando a existir, o homem se credencia para morrer a sua própria morte, que se apresenta, em relação à sua vida, como um completamento e uma apoteose.

Hetério, do grego héteros, protagonista de "Azo de almirante" (ROSA, 1979, p. 24-26), é aquele que, no instante crucial de sua vida, em vez de deixar-se anular pela esmagadora sorte adversa, inventou-se outro e se reespiritou, recusando a fatalidade. $\mathrm{O}$ pleno desempenho de seu nome está expresso na frase "Ao adiante, assim às águas outras e outras. No rio nada durava" (p. 25). No elemento líquido, a vida perpetuamente se reinicia. A legenda da água é a do ser deveniente, cuja essência consiste em deformar-se. $\mathrm{O}$ rio só se assemelha a si mesmo na medida em que náo cessa de diferir de si próprio. O homem devotado ao elemento aquático é o ser em vertigem, que morre a todo momento, pois, instante após instante, algo de sua substância se desvanece e se esfaz. Sempre e para sempre, a água escorre e se esvai. Viver em consonância com o mobilismo hídrico requer, solidárias e contemporâneas, a prontidão para morrer e a disposição para renascer (BACHELARD, 2013).

$\mathrm{O}$ incessante movimento das águas registra a fuga perpétua do tempo e sugere a constante solicitação à metamorfose, que ensina a extrair, da própria negação, a solerte afirmaçấo. Num Dilúvio, teve início a era bíblica; na "grande enchente de arrasar", 
teve Hetério o "começo de seus caminhos" (p. 24). As águas que hoje rolam e desandam, formando o estrago de um "de repente mar", são "as águas antepassadas" (p. 24) da grande inundação, o mesmo princípio regendo o fenômeno outrora e agora, a mesma estranha solidariedade entre a destruição e a criação, resumidas no governo do "Espírito Solto" - Espírito, de Santo, e Solto, do Demônio - que orquestra a inextricabilidade da vida e da morte.

Esta mesma associação do elemento vital e do fator mortal comanda a reversa harmonia da fatalidade e da graça, que se aliam, operando o "super-humano ato pessoal" de Hetério, análogo ao feito do louco herói de "Darandina" (ROSA, 1981, p. 121): "Em fatal ano da graça, Hetério se sobressaíra" (p. 24). É na dificuldade que o herói se distingue. "Com o que outro míngua, eu me sobejo", dissera Joaquim Norberto, o herói de "Luas-de-Mel" (ROSA, 1981, p. 97). A desgraça é o suporte invisível de uma graça superior. "O gênio é punhal de que não se vê o cabo", resume oportunamente o narrador. As coisas importantes "começam deveras é por detrás do que há", ensina o narrador de "Antiperipleia" (ROSA, 1979, p. 13). As citaçóes oportunamente buscadas em outras estórias - "primeiras" ou "terceiras" - comprovam a centralidade desta "transmutação existencial" como mote essencial da poética rosiana do existir.

Sob o influxo da terrível cheia, numa "antiperipleia", vale dizer, numa viagem de volta à origem, Hetério retornou ao início dos tempos e "teve entáo a suscitada" (p. 24). Converteu-se no Senhor do Rio e cumpriu a decisão de se conduzir segundo uma nova modalidade de ser. A suscitada significa que Hetério ressuscitou dos mortos, isto é, despertou de entre as almas que dormem e limitam-se a subsistir corriqueiramente. Ele, que nunca havia vencido o "fastio de viver, sem hálito nem bafo" (p. 24), autodeterminou-se como "o em posição personificada" (p. 25), "personagente", "psiquiartista", como o louco de "Darandina" (ROSA, 1981, p. 124 e p. 132), forjando para si uma "novidade de caráter" de modo que "não se pareceu mais com ninguém" (p. 24). Ele suscitou o outro de si mesmo. A morte da mulher e das filhas promove o seu renascimento. Em vez de queixar-se da sorte, ele "não exclamou" (p. 24), e traçou um destino inesperado, incessantemente cambiante, ao sabor das águas vogantes do rio. Mais uma vez, a pertinência de se atribuírem a Hetério as qualificaçôes de outro personagem do universo poético de Rosa ratifica a solidariedade intrínseca deste universo e atesta o compromisso ético e poético que mobiliza a sua obra.

Executando a invençáo de se integrar ao rio, construindo a sua morada na deveniência do elemento líquido, Hetério se aproxima do Pai de "A terceira margem do rio". Afeito à terceira margem, Hetério "arranjou-se ao travessio" (p. 24), e dedicou-se a transpor, de banda para banda, em sua "canoa barcaçosa, a caravela com caveiras", tanto vivos (cortejos de noivos, troços de soldados, gente) quanto mortos (enterros), reunindo em si as figuras contrárias de Noé, o timoneiro da vida, e de Caronte, o barqueiro da morte (p. 24/25). Doravante, a travessia se torna o moto perpétuo de sua existência. Suas viagens pelo rio versavam bodas, festas, funerais, fé e negócios. A di- 
versidade de funçóes que realizava o fazia mudar constantemente e assumir diversos desempenhos - herói, negociante, barqueiro, guerreiro. Os papéis que desempenhava constituíam a legítima realidade de um existir sempre alterno.

"Vogavante" (p. 26) em vida, "ébrio por dentro" (p. 24) da excessividade do rio, portando-se em consonância com as águas, Hetério morre como o "vogavagante" (p. 26), quando a sua canoa vaga à deriva, "desconduzida" por um piloto ferido. No "travessão do Fervor" (p. 26) - nome duplamente apropriado, por evocar a existência em ritmo de transe e por assinalar o entusiasmo vital do canoeiro - Hetério morre, e a sua morte é um "completamento" (p. 26). O toponímico "Fervor" dá à sua morte um caráter religioso, votivo, e a brusca ruptura do "travessão" pontua diversamente a existência de Hetério, dando início à derradeira travessia. Para um que chegou a existir, cabe o merecimento de uma morte própria, consumada e arrumada por "ele mesmo", em perfeito acordo com a sua índole de "popeiro proezista":

Adiante, no travessão do Fervor, itaipava perigosa, a canoa fez rombo. Ainda ele mesmo virou-a entáo, de boca para baixo, num completamento. Safo, escafedeu-se de espumas, braceante, alcançou o brejo da beira, onde atolado se aquietou. Acharam-no - risonho morto, muito velho, velhaco - a qualidade de sua pessoa (p. 26).

"Popeiro proezista" (p. 26) é aquele que alia os dois movimentos contrários que impelem tanto para a frente (proa) quanto para trás (popa), coordenando um contínuo ir e vir ao doce "sabor de oscilar" e antecipando o ritmo dialético de um outro mestre na arte de "outrar-se" (Prebixim, de "O outro ou o outro") (ROSA, 1979, p. 106). Converte-se assim o seu ofício (popeiro) na constante proeza de um fazer renovado proezista - palavra em que se superpóem a "proa" e a "proeza". A "qualidade de sua pessoa" fez dele um "risonho morto", "vestido de funesto e intimado de venturoso" como o transitoriante Tio Man'Antonio de "Nada e a nossa condiçáo" (ROSA, 1981, p. 73), companheiro de andanças no devir. "O rio não deixa paz ao canoeiro", afirma o narrador. Na infixabilidade das águas que passam, tendo de firmar o passo onde não há solo, começa o homem verdadeiramente a afirmar o seu destino, deixando de ser inerme e inerte para rearvorar-se como o condutor do seu próprio leme. É de notar que, mesmo na hora extremosa, Hetério velhacamente levou a melhor sobre o acidente e conduziu-se a si mesmo ao repouso final, escafedendo-se de espumas e braceando até o brejo da beira, onde "se aquietou". Sobressaem ainda na passagem citada as inúmeras aliteraçōes e assonâncias, que orquestram o ritmo de um morrer harmoniosamente coordenado ao viver que se elegeu.

Sensível ao viver sempre outro de Hetério, o narrador imprime à narrativa o mesmo ritmo sincopado que caracterizou a vida do personagem. Recusando a linearidade, a narrativa alterna-se entre o presente e o passado, com alusóes que antecipam o futuro, desenhando o quadro completo da existência de um humano que se superou ao protagonizar um "transe hiperbólico", para usar mais uma vez os "distin- 
tivos" da açáo do personagente de "Darandina" (ROSA, 1981, p. 121). Os comentários que resumem e esclarecem o sentido da estória e a manipulaçáo temporal nas constantes idas e vindas do enredo são a marca do narrador autoral, que, tal um popeiro proezista, governa o leme narrativo de modo a chegar a um destino certo. A condução autoral da narrativa permitiu condensar, em breves e precisas pinceladas, o passado pálido, o presente que desperta, suscitando um novo sentido, e o futuro que se apresenta como a consagração de uma existência que soube dar o salto mortale propugnado pela estória "O espelho" (ROSA, 1981, p. 68). Importa menos aqui a interioridade reflexiva de Hetério, o palco de sua consciência - até porque ele "não exclamou", já que, como afiança o narrador, "cerrando bem a boca é que a gente se convence a si mesmo" (p. 25) - do que o amplo painel de sua existência, imagem dinâmica de uma vida "que tem assunto", como a do Romão, de "Reminisção" (ROSA, 1979, p. 81).

A narrativa começa com o desfile de canoas "enchusmadas e em celeuma", sob o comando "de um Hetério", que se dirigem a uma fazenda onde haverá "alguma desordem" (p. 24). Mais do que a ação, a escolha do vocábulo "enchusmadas" (amontoadas em chusmas) traduz a agitaçáo que comove o deslocamento maciço. Antes que se saiba o motivo da expedição, o narrador provoca um corte brusco para narrar "eventos vários", que iluminam a qualidade de pessoa do regente da frota. Como num teatro, para que todos possam ver, a vida de Hetério vai sendo narrada em atos, em que se sucedem os múltiplos lances de um viver identificado com o cursar das águas. Um curto parágrafo devolve a narrativa ao combate que se prepara, mas o narrador, mão no leme, decide que "ainda não" é hora de concluir, pois antes do desfecho glorioso "outros atos" se seguiram (p. 25). O encontro com Normão, "homem apaixonado, na maior imaginação", que queria reaver sua mulher, é o ponto de contato entre o para-a-frente e o para-trás, a proa e a popa da narrativa.

Normão e Hetério travam conhecimento num local onde "a paisagem tomava mais luz", fazendo-se "mais espelho" a represa, lisa, que absorvia e refletia a luminosidade solar (p. 26). Nesse espelho das águas, local propício a uma descida na profundidade mais íntima, e com toda a carga simbólica que o espelho assume dentro do universo das estórias rosianas, projeta-se o derradeiro ato do solo vital de Hetério. O passado enfia-se no presente e estica-se até o futuro, fechando a ação que se delineara e concluindo a viagem existencial de Hetério. Vida e narrativa confluem para celebrar o gran finale do personagente. Na "Fazenda-do-Calcanhar", aonde liderara o seu "lóide de canoas" na elevada missão de resgatar uma esposa para o seu amado, Hetério encontra o seu fim. A fazenda, "beiradeâ" (p. 26), assinala um limite, além do qual já se está na terceira margem. O calcanhar, por sua vez, traz à mente o desempenho heroico do grande guerreiro. O lendário calcanhar de Aquiles é prenúncio de término, desfecho anunciado, morte que não se adia, mas é também, e principalmente, fama que se conquista, transe que não se esquece, passaporte para a grandeza e para a imortalidade. 


\section{ATRAVESSAR, COMO QUEM ABRE ENFIM OS OLHOS: "Ripuária"}

A disposiçáo de alternar de um lado a outro revela que, mais do que situar-se de cá ou de lá, importa suspender-se no pérvio, entre os extremos que se opóem, constituindo uma terceira dimensão, que não é uma nem a outra, nem a soma das duas, mas $\mathrm{o}$ acordo de complementaridade, mediante o qual uma incessantemente à outra se doa. Além e aquém das margens de cá e de lá, impõe-se o próprio rio, que é a terceira margem. Quem se afaz ao rio, confeiçoando-se ao mover-se sempre alterno das águas, edifica uma morada, cujo permanecer é um manter-se-em-devir. Imanecer no rio significa aportar ao terceiro. Esta é a estória de Lioliandro (ROSA, 1979, p. 134-137).

A estória se constrói sobre uma oposição irreconciliável: "os de cá" x o "lado de lá". "Os de cá" eram os da lida diária, da práxis, da obrigação sempre imediata de viver: "Desta banda se fazia toda comunicação, relaçôes, comércio: ia-se à vila, ao arraial, aos povoados perto" (p. 134). O "lado de lá" (p. 135), ignorado, parecia domínio do sonho, do irreal, e vagamente do mal. Envolta numa aura de mistério e perigo, a banda de lá era uma alternativa inexistente. Os de cá queriam a segurança do uno sempre igual a si mesmo e fechado em sua identidade. Distante e inacessível, o lado de lá saía-se quase mítico, e, por isso mesmo, nefando e proibido. O próprio rio, que chegava ao outro lado, tocando-o e dele se influindo, era visto com desconfiança e votado ao desprezo: "ninguém o passava. Davam-lhe as costas os de cá, do Marrequeiro, ignorando as paragens dele além, até a dissipação de vista, enfumaçadas" (p. 134). Do lado de cá residia a família de Lioliandro, que, como todos "os de cá", era avessa ao "lado de lá" : "João da Areia, o pai", que "conhecia muita gente, no meio redor, selava a mula e saía frequente"; a mãe, "que se mexia como uma enorme formiga" (p. 134); e as irmâs, em idade de casar. Numa azáfama permanente, todos se consumiam em seus afazeres quotidianos, e, da vida, não obtinham mais do que o bruto subsistir.

Menos Lioliandro. Ele "era o único a olhar por cima do rio como para um segredado" (p. 134). Em sua mais profunda natureza, ele era convocado pelo rio, seduzido pela outra margem, e, por isso, de todos divergia, particularmente do pai, com cujo senso prático "descombinava". Como um afluente da estória "A terceira margem do rio", "Ripuária" também se estrutura sobre uma dissonância entre pai e filho, que habitam mundos diferentes e distantes. Lá, o filho nutre uma admiração cheia de espanto pelo pai, que o supera e confunde. Aqui, é o filho que, enxergando muito mais além, ampliando-se de alma, suplanta o pai e se afasta desde logo, ainda que não fisicamente, da família. Lioliandro é "ripuário", quer dizer, "da margem" (HOLANDA, 1986). Mas, enquanto todos são "da margem de cá", ele é apenas da margem, o que "não gostava de se arredar da beira" (p. 134), porque quem está na beira já se encontra no limiar da travessia. Pertencendo intimamente ao rio, ao rebojo das águas, Lioliandro concretiza o anelo irrealizado do filho de lá, da outra estória, de se permanecer nos espaços do rio, "rio abaixo, rio a fora, rio a dentro - o rio" (ROSA, 1981, p. 32). 
O nome "Lioliandro" é um achado linguístico. O nome rola, dança e coleia, como as águas do rio. Lioliandro é o homem ("andro", do grego andrós) que se funde com o formato mexente do rio e assume plasticamente em seu ser o movimento serpeante da água. Existencialmente aderido ao corpo movente das águas, Lioliandro é o homem-rio: "E virava-se para a extensão do rio, longeante, a não adivinhar a outra margem" (p. 134). Mais do que propriamente chegar à outra margem, atraía Lioliandro o transcender em si mesmo, o lançar-se além. O lado de cá afigurava-se-lhe pouco, em descompasso com a sua sensiblidade afeiçoada ao mistério e afeita ao desconhecido. Buscar o outro era o mais próprio de sua índole: "A gente podia vender o chão e ir ..." (p. 134), desejou, quando o pai morreu. Ir, não importava aonde, "longeante", como "o rio-rio-rio, o rio - pondo perpétuo" (ROSA, 1981, p. 31). Não podendo atravessar, ele nadava, "adiantemente, o quanto pudesse, até de noite, nas névoas do madrugar" (p. 134). O rio era a transcensão, a única via de superação da estreiteza da "banda de cá".

Faltava-lhe, contudo, o meio para atravessar. "E veio, nesse tempo, foi uma canoa, sem dono, varada na praia" (p. 135). Aparecida, como por milagre, a canoa vinha favorecer o destino de Lioliandro: "Em mente, achava-lhe um nome: Álvara" (p. 135). A construção da frase e o uso do verbo "achar" comunicam a noção de que alguma coisa maior providenciava para a sorte de Lioliandro, já que a moça por quem ele vai-se apaixonar tem o mesmo nome. Quando, "em mente", Lioliandro acha o nome "Álvara", ele está ouvindo o silêncio a sussurrar-lhe "um segredado". A moça já estava em seu horizonte vital, mas aparecia-lhe, primeiro, sob a forma de canoa, porque, se não lhe aquietasse a alma ávida de travessia, ela não conseguiria chegar ao seu coraçáo. Que a canoa e a moça tenham um único nome é uma combinação altamente poética, bem ao gosto da sensibilidade rosiana. Para um homem-rio, uma moça-canoa. É cosmicamente exato e propício que a travessia do rio coincida com o transe do amor. Álvara é um nome que, por si só, fala de transcendência. A claridade, a musicalidade e a alegria pulsam em seu bojo. O nome "Álvara" canta, brinca e ondeia nas águas do rio, salta as corredeiras, e, no "Passo-do-Contrato", se envia ao outro lado, alvará, permissão de travessia, compasso de harmonia, antecipando o contrato nupcial que os enlaçará.

A travessia era o principal anelo de Lioliandro: "Queria era, um dia, que fosse, atravessar o rio, como quem abre enfim os olhos" (p. 135). Abrir os olhos é ver pela primeira vez. A travessia é uma revelação e uma iniciação. O sentido maior da existência se descerra para Lioliandro no atravessar o rio. A razão manifesta de querer tanto "o acolá da outra aba" é triunfar do menosprezo dos de cá e encontrar o amor:

Talvez ele não sendo o de se ver capaz - conforme sentenciara-o o velho, João da Areia. Decerto, desta banda de cá, dos conhecidos, o desestimavam, dele faziam pouco. Do outro lado, porém, lá, haveria de achar uma moça, e que amistosa o esperava como o mel que as abelhas criam no mato..." (p. 135).

Todavia, mais definitiva do que o manifesto desejo, e mais visceral, provocadora, era a razáo profunda para o tanto aspirar à travessia: Lioliandro era mobilizado por 
uma vocação, arraigada na própria alma, de ir além, ultrapassar, levar-se "adiantemente", transcender.

Três vezes Lioliandro lança-se ao rio em travessia, e Álvara - moça e canoa - está presente nas três. Com a morte do pai, o destino do rapaz ficara preso ao das irmãas. $\mathrm{O}$ pai o designara, e a mãe raivosamente o confirmara, responsável pelo futuro das três. Por isso, suas tentativas de atravessar o rio se imbricam com as bodas das irmãs, dado sintomático e significativo. No dia do casamento das duas mais velhas, Lioliandro ensaia-se no rio pela primeira vez: "Montou entâo uma vez a canoa e experimentou, no remar largo" (p. 135). Por ocasiáo do noivado da irmã caçula, ele se aventura a cruzar realmente o rio, e, desta vez, consegue chegar ao outro lado:

Entretanto provara, para sustos e escândalo, a façanha. De aposta, temeram por sua vida! Desapareceu, detrás das ilhas, e da pararaca, em as rápidas águas atrapalhadas. Só voltou ao outro dia, forçoso, a todo $o$ alento (p. 136).

Para sua surpresa, não encontra "nenhum nada" do lado de lá. O que resta com ele, todavia, como saldo da travessia, é muito mais do que se tivesse encontrado algum algo. Fica-lhe a luminosidade noturna, a luz que se alteia na treva, a amplitude, a abertura que convida: "Dobrava de melancolia. Trouxera a lembrança de meia lua e muitas estrelas: várzeas largas... A praia semeada de vidro moído” (p. 136).

Gradualmente, em sua interioridade, transformações se operavam, após a travessia: "Muito o coração lhe dava novos recados. Lioliandro estudava a solidão. Dela lhe veio alguma coisa" (p. 136). A possibilidade do amor se lhe abrira. Durante a festa de casamento da última irmã, a moça Álvara se desescondia dele, e "ele desencerrava-se" (p. 136). De inseguro, contudo, ele ainda duvidava. Revolvia-se em alvoroço, e da travessia desdenhava, como se incompleta, insuficiente: "A travessia nem lhe valera, devia mais ter-se perdido, em fim, aos claros nadas, nunca, não voltando" (p. 136). O rio registrava essa mudança de alma, e, na manhã seguinte, "rebojado", ele "mudava de pele" (p. 136). O que o rio é, acima de tudo, é mutaçáo perpétua, metamorfose contínua. A alteraçáo na disposição do rio reflete o estado emocional alterado de Lioliandro. Homem e rio, em comunháo, experimentam o mesmo sentir. Na profunda e característica comunhão entre o homem rosiano e a natureza, o rio torna-se a manifestação perceptível da alma de Lioliandro.

A terceira travessia, chancelada pela simbologia do número três, é a consumaçáo da intimidade entre homem e rio. Lioliandro estabelece, com o rio, uma interaçáo física e carnal, e verdadeiramente assimila, em sua própria existência, o fluir caudaloso das águas. Ele e o rio passam a ser o "conteúdo" um do outro:

Entrou, enfiava o rio de frecha, cortada a correnteza, de adeus e adiante, nadava, conteúdo, renadava (p. 136).

Esta travessia acontece na plena claridade do dia, enquanto a outra se dera na escuridão da noite. Aquela fora a bordo da canoa, esta, no incontido ímpeto do próprio 
corpo. Dupla e integralmente o rio estava conquistado. A fusão de Lioliandro com a massa das águas era total. Nesse transe, lembram-lhe as palavras do pai: " - 'Não posso é com o tal deste rio!" (p. 136). Ele, Lioliandro, por sua vez, o transpusera duas vezes, de dois modos diferentes. Definitivamente, ele transcendia e superava "os de ca": "Sacudiu dos dois lados os cabelos e somente riu, escorrido cuspindo" (p. 136). Sacudindo os cabelos "dos dois lados", Lioliandro reafirma o seu poder de oscilar de cá e de lá, de realizar-se como trânsito, de definir-se em travessia. Esta ambivalência o situa além, e acima, dos que "o desestimavam". A duplicidade é o dom de alternar, que Lioliandro compartilha com o próprio rio.

É digno de nota o esforço, na tessitura fônica da linguagem em que é vazada a passagem acima, para manifestar sonoramente o embate do rapaz com o rio. De início, a aliteração da fricativa / f/ em "enfiava de frecha" traduz o meter-se, réptil, pela massa das águas, como quem está em seu elemento. A seguir, a aliteração da oclusiva velar /k/ em "cortada a correnteza" captura o gesto de resistência das águas, na tentativa de travar o avanço do nadador. Por fim, triunfando dos obstáculos, Lioliandro desliza macio e fácil pelo rio, vitória e facilidade impressas na assonância luminosa da vogal /a/ em "adeus e adiante". Engenhosamente, contudo, a maciez do /a/ se conjuga e se alterna, na parte final da frase, com a dental vozeada /d/ - "de adeus e adiante, nadava, conteúdo, renadava" - jogo sonoro que apreende e encena o ritmo cadenciado e coleante do nado, na coreografia do corpo-a-corpo homem-rio.

Três são as travessias, e a terceira é a mais completa e total. É na terceira que o amor se manifesta, aparecendo como resultado da travessia, e, ao mesmo tempo, como a sua causa, elemento propiciador. Na terceira travessia, o chamado de Álvara resgata Lioliandro das águas turbulentas, mas com ela, moça $\boldsymbol{e}$ canoa, ele para sempre permaneceria no rio:

Súbito então se voltou, à voz a chamar seu nome: por entre o torto ondear, que ruge-ruge mau moinhava enrolando-o, virou e veio (p. 137).

Nesse momento, ela se revela para o rapaz: " - 'De lá vim, lá nasci". Álvara era a moça de lá, e somente ela poderia trazer a Lioliandro a grande revelação: "Tudo é o mesmo como aqui..." (p. 137). Ora, se a banda de lá é tal e qual a banda de cá, o mistério reside mesmo é no próprio rio. O lado 1 e o lado 2 apenas se situam em margens opostas, mas constituem a mesma unidade unitária e monovalente. Apenas o rio é 3 , terceira margem, unidade trinitária. A moça que veio de lá pertencia com Lioliandro, porque ele sempre se sentira alheio e estranho ao lado de cá. Entretanto, um sentido maior se desprende das palavras que encerram a estória. Quando a moça diz "Sou também da outra banda", o também reúne Álvara e Lioliandro na terceira margem do rio, porque, se um é da margem de cá, e o outro, da margem de lá, não pode haver também, senão numa banda que não é esta nem aquela, mas uma outra, que inclui e transcende as duas que se opôem. A outra banda, à qual os dois pertencem, é o Amor, reino do Terceiro, que só pode realizar-se transripuariamente. 


\section{REFERÊNCIAS BIBLIOGRÁFICAS}

ARNOU, René. Praxis et Theoria. Étude de détail sur le vocabulaire et la pensée des Ennéades de Plotin. Paris: Félix Alcan, 1921.

BACHELARD, Gaston. A água e os sonhos. Ensaio sobre a imaginação da matéria (T. de Antonio de Pádua Danesi). São Paulo: Martins Fontes, 2013.

BERDIAEV, Nicolas. Esprit et liberté (t. de I. P. et H. M.). Paris: Desclée de Brouwer, 1984. Le sens de la création (t. de Lucienne Julien Cain). Paris: Desclée de Brouwer, 1955.

BLANCHOT, Maurice. L'espace littéraire. Paris: Gallimard, 1955.

CORBIN, Henri. Creative Imagination in the Sufism of Ibn'Arabi (translated by Ralph Manheim). Princeton: Princeton University Press, 1969.

HOLANDA, Aurélio Buarque de. Novo dicionário da língua portuguesa. Rio de Janeiro: Nova Fronteira, 2. ed., 1986.

LORENZ, Günther W. "Diálogo com João Guimarães Rosa”. In: - Diálogo com a América Latina (t. de Fredy de Souza Rodrigues). São Paulo: Editora Pedagógica Universitária, 1973, p. 313323.

MENDONÇA, Alexandre. A margem à margem das margens. Range Rede, no 2, 1996, p. 22-27.

PLOTINO. Ennéade VI (traduit par Émile Bréhier). Paris: Les Belles Lettres, 2 vols., 1954.

RILKE, Rainer Maria. Cartas a um jovem poeta (t. de Paulo Rónai). São Paulo: Editora Globo, 17. ed., 1989.

Les élégies de Duino et les sonnets à Orphée (t. de J.-F. Angelloz). Paris: Aubier, 1943.

ROSA, João Guimarães. Primeiras estórias. Rio de Janeiro: José Olympio, 12. ed., 1981.

Tutameia. Terceiras estórias. Rio de Janeiro: José Olympio, 5. ed., 1979.

Grande sertão: veredas. Rio de Janeiro: José Olympio, 7. ed., 1970.

UNDERHILL, Evelyn. Mysticism (A Study in the Nature and Development of Man's Spiritual Consciousness). New York: Meridian Books, 1955. 